Published in final edited form as:

J Mammary Gland Biol Neoplasia. 2013 March ; 18(1): 63-73. doi:10.1007/s10911-013-9273-9.

\title{
Metals and Breast Cancer
}

\section{Celia Byrne,}

Uniformed Services University of the Health Sciences, Bethesda, MD, USA

Shailaja D. Divekar, Departments of Oncology and Biochemistry and Molecular \& Cellular Biology, Lombardi Comprehensive Cancer Center, Georgetown University, Washington, DC, USA

\section{Geoffrey B. Storchan,}

Departments of Oncology and Biochemistry and Molecular \& Cellular Biology, Lombardi Comprehensive Cancer Center, Georgetown University, Washington, DC, USA

Daniela A. Parodi, and

Departments of Oncology and Biochemistry and Molecular \& Cellular Biology, Lombardi Comprehensive Cancer Center, Georgetown University, Washington, DC, USA

\section{Mary Beth Martin}

Departments of Oncology and Biochemistry and Molecular \& Cellular Biology, Washington, DC, USA; Georgetown University, Lombardi Comprehensive Cancer Center, Research Building, 3970 Reservoir Road NW, Washington, DC 20007, USA

\begin{abstract}
Metalloestrogens are metals that activate the estrogen receptor in the absence of estradiol. The metalloestrogens fall into two subclasses: metal/metalloid anions and bivalent cationic metals. The metal/metalloid anions include compounds such as arsenite, nitrite, selenite, and vanadate while the bivalent cations include metals such as cadmium, calcium, cobalt, copper, nickel, chromium, lead, mercury, and tin. The best studied metalloestrogen is cadmium. It is a heavy metal and a prevalent environmental contaminant with no known physiological function. This review addresses our current understanding of the mechanism by which cadmium and the bivalent cationic metals activate estrogen receptor-a. The review also summarizes the in vitro and in vivo evidence that cadmium functions as an estrogen and the potential role of cadmium in breast cancer.
\end{abstract}

\section{Keywords}

Estrogens; Estrogen receptor; Metalloestrogens; Metals; Endocrine disruptors; Breast cancer 


\section{Introduction}

It has been suggested that the high incidence of hormone related diseases, such as breast cancer, is due, in part, to the presence of environmental estrogens. In fact, a number of chemicals present in the environment demonstrate estrogenlike activity [1]. Phytoestrogens, such as coumestrol and the isoflavone genistein, are naturally occurring nonsteroidal compounds that are derived from plants, while xenoestrogens, such as bisphenol A, and the polychlorinated biphenyls dicholorodiphenyltrichloroethane and its metabolite p, p'dichlorodiphenyl dichloroethylene, are synthetic chemicals that activate the estrogen receptor (ER). Many of the phytoestrogens are flavonoids whereas the xenoestrogens are a structurally diverse group of compounds that have no common structural motif. Many have one or two aromatic rings and may be chlorinated giving them a negative charge. In contrast to phytoestrogens and xenoestrogens, metalloestrogens are small ionic metals and metalloids that also activate the estrogen receptor. The metalloestrogens fall into two separate subclasses, oxyanions that include arsenite, antimony, nitrite, selenite, and vanadate and bivalent cations that include cadmium, calcium, cobalt, copper, nickel, chromium, lead, mercury, and tin [2-10]. This review focuses on the bivalent cationic metalloestrogens and addresses our current understanding of their mechanism of action and role in breast cancer.

\section{Estrogen Receptor-Alpha Structure and Function}

Many of the actions of estrogens in the breast are mediated by two isoforms of the estrogen receptor, ERa and ER $\beta$. The mitogenic actions of the hormone are mediated by ERa while the anitmitogenic actions are mediated by ER $\beta$ [reviewed in 11]. Although ERa is a ligand activated transcription factor that belongs to the superfamily of nuclear receptors [12], the receptor has both genomic and nongenomic functions. Similar to other nuclear receptors, $\mathrm{ERa}$ is divided into regions A through $\mathrm{F}$ (Fig. 1) [13]. The N-terminal A/B region contains the transactivation function-1 (AF-1) domain that is involved in protein-protein interactions and plays an important role in ligand-dependent and - independent activation of the receptor. Region $\mathrm{C}$ is the DNA binding domain and consists of two zinc finger motifs that are responsible for binding to estrogen response elements (ERE) in target genes. Region D is the hinge region and plays a role in dimerization of the receptor. Region $\mathrm{E}$ is the hormone, or ligand, binding domain (LBD) and contains the transactivation function-2 (AF-2) domain. The LBD is the most structurally and functionally complex region of the receptor that is responsible for ligand dependent activation, dimerization, and recruitment of cofactors to the receptor. In the absence of hormone, ER $a$ is associated with a complex containing heat shock proteins and immunophilins that maintains the LBD in a high affinity, ligand binding conformation and prevents the receptor from dimerizing and binding to DNA and cofactors $[14,15]$ (Fig. 2). Following the binding of estradiol, the receptor is phosphorylated on serines in the A/B region that increases the activity of the AF-1 domain $[16,17]$ and a conformational change occurs in the LBD leading to the dissociation of the heat shock complex and the formation of the AF-2 domain, the coactivator binding site [18]. In the classical genomic pathway, the activated receptor then localizes in the nucleus, dimerizes, binds to an ERE, and recruits coactivators and RNA polymerase II to the promoters of target genes. In the nongenomic pathway, ER $a$ activates the ERK1/2 and PI3-K/Akt signal transduction pathways [reviewed in 19, 20]. 
The ligand binding domain of ER $a$ is also structurally similar to other nuclear receptors [18, 21-26] (Fig. 3) and contains 11 alpha helices (H1, H3-H12) folded into a three layered antiparallel $a$-helical sandwich. The central core of the LBD contains the ligand binding pocket that is formed by helices $\mathrm{H} 5 / 6, \mathrm{H} 9$, and $\mathrm{H} 10$ inserted between two layers of helices composed of $\mathrm{H} 1-4, \mathrm{H} 7, \mathrm{H} 8$, and $\mathrm{H} 11$ with helix $\mathrm{H} 12$ flanking the ligand binding pocket [24]. Based upon the crystal structure of RXR- $a$ in the absence and presence of its ligand $[23,27]$, several major conformational changes are thought to occur in the LBD as a result of estradiol binding in the pocket (Fig. 3). In the absence of estradiol, helices H10 and H11 are separated by a short loop with helix H11 positioned at an angle to helix H10 and helix H12 positioned to the side of the pocket. As a result of hormone binding in the pocket, helix H12 is repositioned over the ligand binding pocket and helix H11 is repositioned adjacent to helix H10 forming a continuous helix. In the activated receptor, the repositioning of helix H12 over the central core creates the AF-2 domain and the newly formed helix H10/H11, together with helices $\mathrm{H} 8$ and $\mathrm{H} 9$, constitutes the dimerization domain.

\section{Cross Talk Between Signal Transduction Pathways and ERa}

In addition to estradiol, ER $a$ is activated by growth factors and cytokines [28], however, the mechanisms by which their downstream signaling pathways cross talk with ER $a$ are not fully understood. Growth factors and cytokines are thought to activate the receptor, in part, through the phosphorylation of the N-terminal AF-1 domain [29] and through the posttranslational modification of coactivators [30]. Growth factors, such as EGF and IGF-1, activate the Ras-Raf-MEK-MAPK kinase and PI3K-AKT pathways resulting in the phosphorylation of serines in the $\mathrm{N}$-terminal $\mathrm{A} / \mathrm{B}$ region of the receptor [reviewed in 31]. Although phosphorylation of the $\mathrm{A} / \mathrm{B}$ region is responsible for the activation of the AF-1 domain, it does not account for the conformational changes necessary for the activation of the AF-2 domain suggesting that additional intracellular events are required for the activation of the C-terminal LBD. Calcium is a bivalent cationic metal and a second messenger in signal transduction pathways. Recent studies show that calcium mediates the cross talk between growth factor/cytokine signaling pathways and the LBD of ER $a$ and more importantly, that calcium is a ligand of ER $a$ that activates it in the absence of estradiol [8]. Activation of ER $a$ by calcium in breast cancer cells results in the induction of estrogen responsive genes and in hormone independent proliferation.

In contrast to estradiol that binds in the ligand binding pocket, calcium binds and activates ER $a$ through sites on the surface of the LBD [8]. The calcium interaction sites are located at the ends of helices that are repositioned upon activation of the receptor suggesting that the interaction of calcium with these sites induces a conformational change in the LBD similar to the conformational change induced by estradiol (Fig. 3). By interacting with different amino acids in a protein, metals, such as calcium, can alter secondary structure, promote local folding, and assemble different regions into one domain. In the lipase enzyme of Pseudomonas for example, the active site of the enzyme is covered by a lid that is formed by two helices separated by a turn. The interaction of calcium with amino acids on the two helices repositions the helices and opens the lid [32]. In the case of ER $a$, there are four potential calcium interaction sites in the LBD [8]. One of the calcium interaction sites is located at the interface of helices $\mathrm{H} 10$ and $\mathrm{H} 11$ suggesting that the interaction of the metal at 
the interface of the helices converts the helix-loop-helix structure of the inactive conformation into a continuous helical structure, helix H10/H11, in the active conformation (Fig. 3). Two of the calcium interaction sites are located at the ends of helices; one site is on the C-terminal end of helix $\mathrm{H} 11$ and one site is on the N-terminal end of helix H12 suggesting that the interaction of the metal with these sites repositions helix H12 over the ligand binding pocket. The fourth calcium interaction site is located on helix 4 in close proximity to helix $\mathrm{H} 12$ suggesting that the fourth site may contribute to the repositioning and closing of helix $\mathrm{H} 12$ over the ligand binding pocket and the formation of the coactivator binding site. The proposed model, that calcium activates ER $a$ by inducing conformational changes in the ligand binding domain that mimic the conformational changes induced by estradiol, remains to be tested.

The ability of calcium to mediate the cross talk between growth factors/cytokines and the LBD of ER $a$ and to activate the receptor in the absence of estradiol suggests that the bivalent cationic metalloestrogens activate ER $a$ by mimicking calcium. In support of this hypothesis, cadmium replaces calcium in many biological systems and assays [33-35]. In the case of ER $a$, cadmium and the other bivalent cationic metalloestrogens activate it through the LBD and require the same amino acids (cys381, glu523, and asp538) as calcium [3, 5]. Cadmium also competes with calcium for binding to the LBD of the receptor [8]. An ionic charge of +2 appears to be important as chromium(II), a bivalent cation, activates ER $a$ whereas, chromium(III), a trivalent cation, does not activate the receptor [3]. Although an ionic charge of +2 appears to be an important attribute of this subclass of metalloestrogens, not all bivalent cations activate ER $a$, e.g., zinc, a bivalent cation, does not activate $\operatorname{ER} a$ [3, $5,36]$. Many of the bivalent cationic metalloestrogens also have an effective ionic radius that is similar to calcium. In addition to having a charge and ionic radius similar to calcium, the bivalent cationic metals bind with high affinity to the LBD and noncompetitively block the binding of estradiol [3, 5, 37]. Several studies demonstrate a high affinity interaction of cadmium with the LBD that blocks the binding of estradiol, whereas other studies fail to show that the metal interacts with human ER $a$ and blocks the binding of hormone [3, 38]. The differences between the studies that demonstrate specific binding of cadmium to the receptor and studies that fail to demonstrate binding may be attributed to differences in experimental conditions. In whole cell binding assays with endogenously [3] or exogenously expressed ER $a[3,38]$, the intracellular concentrations of naturally occurring metal chelators, such as glutathione, can influence the binding of cadmium to the receptor. In cellfree binding assays with either purified full length receptor [37] or purified recombinant LBD [3], the concentrations of preservatives, such as dithiothreitol, and metal chelators, such as EDTA, can also influence binding of the metal. In addition, temperature [38], order of addition, and incubation time [3] can alter the binding of cadmium to ER $a$ as well as the ability of the metal to block the binding of estradiol to the receptor. Although less well studied, other bivalent cationic metals mimic the binding of calcium to ER $a$. Chromium(II), copper, cobalt, nickel, lead, mercury, and tin bind with high affinity to the receptor, block the binding of estradiol, and interact with the same amino acids in the ligand binding domain [5]. The ability of cadmium and the other metals to mimic the ability of calcium to bind to the LBD and to require the same amino acids to activate the receptor suggests that bivalent cationic metalloestrogens activate ER $a$ by mimicking calcium. 


\section{Estrogen-Like Effects of Metals in Vitro}

There is a growing body of evidence that metalloestrogens activate ER $a$ in vitro. Most of the published studies address the ability of cadmium to activate the genomic and nongenomic pathways of ER $a$ and show that, similar to estradiol, cadmium induces the proliferation of estrogen dependent breast cancer cells [2, 36, 39, 40], increases the transcription and expression of estrogen regulated genes such as the progesterone receptor (PR) [2, 41], activates ERa in transfection assays [2, 3, 36, 39, 42], and increases signaling through the ERK1/2 and Akt pathways [41, 43, 44]. In addition to activating ERa, there is some evidence that cadmium activates the membrane estrogen receptor GPR30 [43]. Although the majority of studies find that cadmium activates ERa, some studies failed to demonstrate an estrogen-like effect of the metal. One study failed to find an estrogen-like effect of cadmium in breast cancer cells or in yeast that expressed the human ERa [45]; a second study also failed to find a genomic effect but demonstrated a nongenomic effect of the metal in breast cancer cells [44]. Cell culture conditions may explain, in part, the inability of cadmium to activate ERa in vitro. Our experience has been that the presence and amount of sulfates, phosphates, lipoic acid, and the polyanion putrescine in the culture media and the presence of sulfates in sulfatase-treated stripped serum interferes with the ability of the metal to elicit an estrogenlike response in vitro (unpublished data). Sulfates and phosphates form weak and insoluble cadmium salts while lipoic acid and putrescine chelate metals. Although less well studied, there is also evidence that the other bivalent metals activate ERa in vitro [5, 36, 46]. Copper, cobalt, nickel, lead, mercury, tin, and chromium(II) induce the proliferation of estrogen dependent breast cancer cells [5, 36, 46], increase the transcription and expression of estrogen regulated genes [5], and activate ERa in transfection assays $[5,36]$ supporting the estrogen-like effects of these bivalent cationic metals in vitro.

\section{Estrogen-Like Effects of Metals in Vivo}

There is also increasing evidence that cadmium activates the genomic and nongenomic pathways of ERa in vivo [4, 47-55]. The rodent uterotropic response assay is the most commonly used laboratory model to test for the estrogenicity of compounds in vivo. Traditionally, ovariectomized pubertal and adult rats are employed in the assay but ovariectomized pubertal and adult mice are also used [56]. In more recent studies, immature animals rather than ovariectomized adult animals were employed because developing tissues are thought to be more susceptible to perturbation by hormones [57]. In the uterotropic assay, the estrogenicity of a compound is determined by measuring one or more endpoints including the ability of the compound to increase uterine wet weight, increase epithelial cell height and number, increase the number of glands, and induce the expression of estrogen responsive genes such as progesterone receptor and complement $\mathrm{C} 3$. In addition to measuring endpoints in the uterus, the estrogenicity of a compound can be measured in the mammary gland by its ability to enhance development of the gland and to induce the expression of estrogen responsive genes. In the case of cadmium, the estrogenicity of the metal has been measured in the uterus and mammary glands of immature and ovariectomized rats and mice. In Sprague-Dawley rats ovariectomized at 28 days of age and treated 3 weeks later with a single intraperitoneal (ip) dose of cadmium of $5 \mathrm{ug} / \mathrm{kg}$ body 
weight (bw), treatment with the metal resulted in a significant increase in weight and expression of the estrogen regulated genes $\mathrm{PR}$ and complement $\mathrm{C} 3$ in the uterus and a significant increase in epithelial density and expression of PR and complement $\mathrm{C} 3$ in the mammary glands [4]. More importantly, the estrogen-like activity of cadmium was blocked by an antiestrogen [4]. In contrast to animals ovariectomized at 28 days of age, a higher dose of cadmium of $800 \mathrm{ug} / \mathrm{kgbw}$ administered intraperitoneally for 3 days was needed to obtain a significant increase in uterine weight in Sprague-Dawley rats ovariectomized at 23 days of age and treated 3 weeks later [49] suggesting that the age at the time of ovariectomy influences the estrogenic activity of cadmium. The route of exposure also influences the estrogenic activity of the metal. In Wistar rats ovariectomized at 28 days of age and treated 2 weeks later, a single intraperitoneal dose of cadmium ranging from $50 \mathrm{ug} / \mathrm{kgbw}$ to $2 \mathrm{mg} /$ kgbw resulted in a dose dependent increase in uterine weight and increased in expression of complement $\mathrm{C} 3$ at the highest dose [48]. In the small intestine, the single intraperitoneal dose of cadmium also resulted in an estrogen-like effect on gene expression [52]. In contrast to intraperitoneal administration, administration of cadmium by gavage for 3 days at doses ranging from $50 \mathrm{ug} / \mathrm{kgbw}$ to $4 \mathrm{mg} / \mathrm{kgbw}$ or through drinking water for 28 days at doses ranging from $400 \mathrm{ug} / \mathrm{kgbw}$ to $9 \mathrm{mg} / \mathrm{kgbw}$ had no effect on uterine weight [48, 52]. However, there was an estrogen-like effect on gene expression in both the uterus and small intestines $[48,52]$. A similar dose effect of cadmium on uterine weight following intraperitoneal administration was also observed in Wistar rats ovariectomized at 28 days of age and treated 3 weeks later with either $120 \mathrm{ug} / \mathrm{kgbw}$ or $1.2 \mathrm{mg} / \mathrm{kgbw}$ for 3 days [53], or in Wistar animals ovariectomized at 35 to 42 days of age and treated 2 weeks later with a single dose of either $50 \mathrm{ug} / \mathrm{kgbw}$ or $2 \mathrm{mg} / \mathrm{kg}$ bw [55]. In the former study, the increase in uterine weight was accompanied by an increase in phosphorylation of ERK [53] and in the latter study, the increase in uterine weight was accompanied by an increase in PR and complement C3 expression [55] suggesting that exposure to cadmium activates both the nongenomic and genomic pathways in vivo. The estrogen-like effects of the metal have also been studied in mice. In immature mice, subcutaneous administration of cadmium at a dose of 5, 50, or 500 $\mathrm{ug} / \mathrm{kgbw}$ for 3 days had no effect on uterine weight but increased the height of the uterine luminal epithelium in a dose dependent manner [50]. In contrast to low doses of cadmium, intraperitoneal administration of a much higher dose of cadmium $(3 \mathrm{mg} / \mathrm{kg}$ bw for 5 days per week for 2 weeks) to immature CD-1 mice resulted in a decrease in uterine weight [47]. However, as the animals aged (4 months old), intraperitoneal administration of cadmium (2 $\mathrm{mg} / \mathrm{kgbw}$ given 5 days per week for 7 weeks) increased uterine weight and mammary gland development as measured by an increase in the development of lobuloalveolar structures [47]. Interestingly, when the mice were ovariectomized prior to treatment with cadmium, an estrogen-like effect was observed in the mammary glands but not in the uterus [47]. Together, these studies suggest that the age and hormonal status of the mice influences the estrogenic response to cadmium. Diet also influences the estrogenic activity of the metal. C57BL/6 mice that express the luciferase gene under the control of an estrogen response element were ovariectomized at 4 to 6 months of age and two weeks later were exposed to cadmium for 21 days by gavage ( $1 \mathrm{ug} / \mathrm{kgbw}$ ), in white bread $(17.57 \mathrm{ug} / \mathrm{kgbw})$, or in flaxseed supplemented bread (49.2 ug/kg) [54]. In the animals exposed to cadmium by gavage, there was an increase in uterine weight, an increase in luciferase in the chest, and an increase in progesterone receptor expression in white adipose tissue. However in the animals exposed to 
cadmium in white bread, there was no increase in uterine weight but an increase in luciferase in the chest, thymus, and white adipose tissue and an increase in expression of prothymosin in the thymus and uterus. Similarly, in animals exposed to the metal in flaxseed supplemented bread, there was no increase in uterine weight but an increase in luciferase in the chest, thymus, and liver and an increase in prothymosin in the thymus and uterus. Taken together, the published studies provide compelling evidence that cadmium activates ERa in vivo and demonstrate that the response depends on the species and strain of rodents, age and hormonal status of the animals, the dose and route of exposure, and the target tissue.

\section{Environmental Exposure to Metals and Breast Cancer}

Metals have diverse biological functions from being essential to toxic and carcinogenic. Metals, such as chromium, cobalt, copper, and nickel, are essential metals required in trace amounts. Essential metals play an important role in metabolism and respiration, in membrane integrity and permeability, and in cell proliferation and death [58-61] where alterations in their concentration may result in disease or toxicity [60, 62, 63]. For example, essential metals at low concentrations function as components of enzymes but at high concentrations can inhibit enzyme activity [61, 62]. Metals, such as cadmium, lead, mercury, and tin, are nonessential metals and exert their toxic effects by mimicking or blocking the function of essential metals $[58,64]$.

Many metals are also carcinogens. Cadmium, chromium, and nickel are established human and animal carcinogens, while copper, lead, and mercury are probable carcinogens or cocarcinogens [65-72]. Occupational exposure to metals including cadmium, chromium, nickel, copper, cobalt, lead, and mercury is associated with an increased risk of lung cancer. Exposure to chromium is also linked to an increased risk of liver, larynx, esophagus, and gastrointestinal cancer. Occupational exposure to cadmium and nickel are linked to renal and prostate cancer and copper exposure is linked to non-Hodgkin's lymphoma and skin cancer. Lead and mercury exposures are associated with glioma and stomach cancers and prostate and bladder cancers, respectively. Women working in dentistry also have an increased frequency of precancerous lesions of the cervix that correlates with the length of employment [73]. In animal studies, nickel, cobalt, mercury, lead, and chromium (VI) induce sarcomas and carcinomas in the breasts, kidneys, lungs, liver, and pancreas and sarcomas at the site of injection [65, 74-77]. While some copper salts produce sarcomas in chickens and mice, other copper salts and chelates suppress the tumorigenicity of chemical carcinogens. There is no experimental data to implicate tin as a carcinogen.

The general population is exposed to metals primarily through the environment. Environmental exposure to cadmium occurs primarily through dietary sources, cigarette smoking, and, to a lesser degree, drinking water [78, 79]. In the United States, dietary studies in the late 1970s and early 1980s found that potato, grain, and cereal products accounted for the largest portion of cadmium intake by the adult male, contributing 24 and $36 \%$, respectively. Fluids, which include drinking water, accounted for $3.2 \%$ of cadmium intake. In the United States, the amount of cadmium exposure from the diet is estimated to range from 0.12 to $0.331 \mathrm{ug} / \mathrm{kgbw} / \mathrm{day}$ with the highest exposure in children 1 to 6 years of age [78-80]. In the Ruhr district of Germany, exposure to cadmium from the diet ranges 
from $0.37 \mathrm{ug} / \mathrm{kg}$ bw/day in adults, $0.49 \mathrm{ug} / \mathrm{kgbw} /$ day in children (mean age 3.8 years), to $0.17 \mathrm{ug} / \mathrm{kgbw} /$ day in young children (mean age 1.8 years) while in Amrum, an island in the German North Sea, cadmium exposure from the diet is $0.39 \mathrm{ug} / \mathrm{kg}$ bw/day in adults and 0.35 ug/kgbw/day in children [65, 81, 82]. Similar exposures are seen in the United Kingdom and Sweden, i.e., 0.2 and $0.25 \mathrm{ug} / \mathrm{kg}$ bw/day, respectively [83, 84]. Cigarette smoke is also an important source of human exposure to cadmium, reflecting the high efficiency of pulmonary absorption of the inhaled metal $[69,85]$. Cadmium intake from one pack of cigarettes per day is estimated to be from 2 to $4 \mathrm{ug}$. The concentration of cadmium in the kidneys of nonsmokers is approximately 15 to $20 \mathrm{ug} / \mathrm{gm}$ tissue, while in smokers, the concentration doubles to 30 to $40 \mathrm{ug} / \mathrm{gm}$ tissue. High concentrations of cadmium are also present in the breasts of healthy women (20 to $30 \mathrm{ug} / \mathrm{gm}$ tissue) [86]. Animal studies show that cadmium can be transferred through the placenta to the developing fetus [87] and that transfer to the fetus is dose related and increases with advancing gestation [88]. Low but detectable amounts of cadmium are found in the gastrointestinal tract, liver, kidneys, and blood of the newborn [87] but by age 30, the body burden may reach $30 \mathrm{mg}$ [89]. The estimated half-life of cadmium in the body ranges from 10 to 30 years [69] which may account for the significant accumulation of the metal in the body.

Cadmium is widely distributed in the earth and is mined for use principally in galvanizing and electroplating, in batteries, in electrical conductors, and in the manufacture of pigments, plastics stabilizers, and phosphate fertilizers [90]. The primary source of cadmium in the environment is due to industrial contamination and most contamination is a byproduct of smelters [91]. In the 1980s, the total atmospheric emissions of cadmium were estimated to be about $635,000 \mathrm{~kg}$ annually. The level of cadmium in streams and rivers generally reflects the level of cadmium contamination in the air and soil. Cadmium has been detected in surface water and ground water samples taken at about $70 \%$ of hazardous waste sites. It has been detected in water samples collected from all of the Great Lakes. In a survey in New Jersey, cadmium was detected in $100 \%$ of surface water and ground water samples, where concentrations as high as $405 \mathrm{ug} / \mathrm{l}(3.6 \mathrm{uM})$ were detected. California, Colorado, Idaho, and Maine also had high concentrations of cadmium in surface and ground water samples (340 to 2,000 ug/l, i.e., 3 to $18 \mathrm{uM}$ ). Although cadmium levels are high in many water sources, most drinking water in the United States probably does not contain more than $1 \mathrm{ug} / \mathrm{l}(9 \mathrm{nM})$. Although most environmental cadmium is due to industrial contamination, water may also contains cadmium as a result of leaching from the soil and the dissolution of cadmium from underlying geologic formations, especially in areas where soft, acidic waters are common. Stratiform deposits with some of the most important cadmium deposits are located in several states, including Missouri, Tennessee, the Missouri/Kansas/Oklahoma border area, the Wisconsin/Illinois border area, and Pennsylvania [90].

Environmental exposure to other metalloestrogens is also significant. In water and soil, the concentrations of chromium, mercury, and copper are 1 to $800 \mathrm{ug} / \mathrm{l}$ and 40 to $459 \mathrm{mg} / \mathrm{kg}$, respectively [92-94]. The amounts of nickel, chromium, mercury, lead, and copper in fish range from $81 \mathrm{ng} / \mathrm{gm}$ to $328 \mathrm{mg} / \mathrm{gm}$ and in grain, the amount of copper ranges from 1 to 14 ug/gm [95]. Exposure of humans to these metals occurs primarily through dietary sources of food and water [96, 97], air, cigarette smoke [59], and occupational exposure [59, 96, 98] and can lead to significant accumulation in the body. The average daily intake of chromium, 
mercury, and nickel is estimated to be from 0.28 to $25 \mathrm{ug} /$ day while the daily intake of copper ranges from 1.46 to $1.63 \mathrm{mg} /$ day [99]. Lead exposure results in significant accumulation in hair and toenails, 3.8 to $10.1 \mathrm{ug} / \mathrm{gm}$ [100] and in breast milk, $36 \mathrm{mg} / \mathrm{l}$ [95].

There is increasing epidemiological evidence linking exposure to cadmium with an increased risk of developing breast cancer. The first study was a hypothesis-generating casecontrol study that examined the death certificates of over 33,000 deaths attributed to breast cancer and over 117,000 non-cancer deaths between 1984 and 1989 [101]. The death certificates were coded for occupation and industry. The study found that occupational exposure to cadmium was associated with an approximate 8 to $20 \%$ increase in breast cancer risk among white women and a 50 to $130 \%$ increase in risk among AfricanAmerican women. As acknowledged by the authors, the method of determining exposure (e.g., a single occupation listed on the death certificate, based on information from a proxy) may have subjected the study to substantial nondifferential misclassification which can markedly attenuate the observed odds ratios leading to an underestimation of risk. In addition, there was no information on other breast cancer risk factors that could have further distorted the results. A second epidemiological study in a retrospective cohort of working Swedish women also suggests a link between occupational exposure to cadmium and an increased risk of breast cancer [102]. In this study, women employed as metal platers and coaters had the highest standardized incidence ratio (relative risk: 2.38). Metal plating and coating exposes workers to cadmium, hexavalent chromium, and organic solvents. A population based case-control study of nonoccupationally exposed women in Wisconsin, that measured cadmium in urine, found that women in the highest cadmium quartile had more than a two-fold increased risk of breast cancer (odds ratio [OR]: 2.29; $95 \%$ confidence interval [CI]; 1.3-4.2) compared to women in the lowest cadmium quartile and estimated that approximately $36 \%$ of breast cancer may be attributed to exposure to the metal [103]. A second population based case-control sample of women living in Long Island also found a similar association [104]. Women in the highest cadmium quartile had more than a two-fold increased risk of breast cancer (OR: 2.69; $95 \% \mathrm{CI} ; 1.07-6.78$ ) compared to women in the lowest cadmium quartile. The latter study also investigated a cross-sectional U.S. probability sample from the National Health and Nutrition Examination Survey (NHANES 1999-2008). In the NHANES sample, the odds for breast cancer were significant and elevated for women in the third cadmium quartile (OR: 2.50; $95 \%$ CI; 1.11-5.63) and marginally significant for the women in the fourth cadmium quartile. Similar to the study of Wisconsin women, the Long Island study estimated that approximately $35 \%$ of breast cancer in the U.S. may be attributed to cadmium exposure. Since the case-control studies were conducted in breast cancer patients, the studies do not clearly establish whether cadmium is associated with the risk of developing breast cancer or is a consequence of the disease. A recent populationbased prospective cohort study shows that long term dietary intake of cadmium is associated with an increased risk of breast cancer in postmenopausal women [105] suggesting a causal effect of cadmium in the development of the disease. Endometrial cancer is also an estrogen related cancer. A population-based prospective cohort study also showed that long term dietary intake of cadmium was associated with a 2.9-fold increased risk of endometrial cancer in postmenopausal women (95\% CI; 1.05-7.79) [106] providing additional evidence linking exposure to cadmium with an increased risk of hormone dependent cancer. Although 
these epidemiological studies suggest a link between cadmium and breast cancer, more experimental and epidemiological studies are required to establish a cause and effect association between exposure to the metal and the development of the disease.

Although not as well studied, there is some evidence linking other metals with estrogen-like activity to breast cancer. The concentrations of copper, cobalt, and tin are significantly elevated in the serum of breast cancer patients and vary with the stage of the disease, the highest concentrations being observed in advanced stages [107-113]. Serum levels of copper are also higher in premenopausal than in postmenopausal breast cancer patients. A marginally significant association is also observed between toenail levels of chromium and breast cancer risk in postmenopausal women but an inverse association is found among premenopausal women [114].

\section{Summary}

Breast cancer is an epidemic, yet the underlying causes of the disease are largely unknown. The prominence of estrogens in the etiology of breast cancer has lead to the suggestion that exposure to environmental estrogens may increase the risk of developing the disease. Metalloestrogens are small ionic metals and metalloids that include metal/metalloid anions and bivalent cations, such as cadmium, calcium, cobalt, copper, nickel, chromium, lead, mercury, and tin. Because metalloestrogens activate the estrogen receptor in the absence of estradiol, exposure to these metals may increase the risk of developing breast cancer. In support of this hypothesis, environmental exposure to many of the metalloestrogens is widespread and has increased significantly over the last 50 to 60 years. Many of the metalloestrogens also have a long biological half life (e.g., cadmium has a half life of 10 to 30 years) and accumulate in the body and in the breast. There is also credible experimental evidence that cadmium activates ERa in vitro and in vivo as well as increasing epidemiological evidence linking cadmium to breast cancer. Although there is evidence linking exposure to the metal with breast cancer, the role of cadmium and other metalloestrogens as causative agents in the etiology of the disease remains to be established.

\section{Abbreviations}

$\begin{array}{ll}\text { AF-1 } & \text { transactivation function-1 } \\ \text { AF-2 } & \text { transactivation function-2 } \\ \text { Akt } & \text { serine/threonine specific kinase } \\ \text { bw } & \text { body weight } \\ \text { EDTA } & \text { ethylenediaminetetraacetic acid } \\ \text { ERa } & \text { estrogen receptor-alpha } \\ \text { ERE } & \text { estrogen response element } \\ \text { ERK } & \text { extracellular signal-regulated kinases } \\ \text { GPR30 } & \text { G protein-coupled receptor 30 }\end{array}$


$\begin{array}{ll}\text { LBD } & \text { ligand binding domain } \\ \text { PR } & \text { progesterone receptor }\end{array}$

\section{References}

1. Colborn T, von Saal FS, Soto AM. Developmental effects of endocrine-disrupting chemicals in wildlife and humans. Environ Health Perspect. 1993; 101:378-84. [PubMed: 8080506]

2. Garcia-Morales P, Saceda M, Kenney N, Kim N, Salomon DS, Gottardis MM, et al. Effect of cadmium on estrogen receptor levels and estrogen-induced responses in human breast cancer cells. $\mathrm{J}$ Biol Chem. 1994; 269:16896-901. [PubMed: 8207012]

3. Stoica A, Katzenellenbogen BS, Martin MB. Activation of estrogen receptor-alpha by the heavy metal cadmium. Mol Endocrinol. 2000; 14:545-53. [PubMed: 10770491]

4. Johnson MD, Kenney N, Stoica A, Hilakivi-Clarke L, Singh B, Chepko G, et al. Cadmium mimics the in vivo effects of estrogen in the uterus and mammary gland. Nature Med. 2003; 9:1081-4. [PubMed: 12858169]

5. Martin MB, Reiter R, Pham T, Avellanet YR, Camara J, Lahm M, et al. Estrogen like activity of metals in MCF-7 breast cancer cells. Endocrinol. 2003; 144:2425-36.

6. Margeat E, Poujol N, Boulahtouf A, Chen Y, Muller JD, Gratton E, et al. The human estrogen receptor alpha dimer binds a single SRC-1 coactivator molecule with an affinity dictated by agonist structure. J Mol Biol. 2001; 306:433-42. [PubMed: 11178903]

7. Veselik DJ, Divekar S, Dakshanamurthy S, Storchan GB, Turner JM, Graham KL, et al. Activation of estrogen receptor-alpha by the anion nitrite. Cancer Res. 2008; 68:3950-8. [PubMed: 18483281]

8. Divekar SD, Storchan GB, Sperle K, Veselik DJ, Johnson E, Dakshanamurthy S, et al. The role of calcium in the activation of estrogen receptor-alpha. Cancer Res. 2011; 71:1658-68. [PubMed: 21212417]

9. Stoica A, Pentecost E, Martin MB. Effect of arsenite on estrogen receptor-a expression and activity in MCF-7 breast cancer cells. Endocrinol. 2000; 141:3595-602.

10. Stoica A, Pentecost E, Martin MB. Effects of selenite on estrogen receptor-a expression and activity in MCF-7 breast cancer cells. J Cell Biochem. 2000; 79:282-92. [PubMed: 10967555]

11. Pettersson K, Gustafsson JA. Role of estrogen receptor beta in estrogen action. Annu Rev Physiol. 2001; 63:165-92. [PubMed: 11181953]

12. Yamamoto KR. Steroid receptor regulated transcription of specific genes and gene networks. Annu Rev Genet. 1985; 19:209-52. [PubMed: 3909942]

13. Kumar V, Green S, Stack G, Berry M, Jin JR, Chambon P. Functional domains of the human estrogen receptor. Cell. 1987; 51:941-51. [PubMed: 3690665]

14. Pratt WB, Galigniana MD, Harrell JM, DeFranco DB. Role of hsp90 and the hsp 90-binding immunophilins in signalling protein movement. Cell Signal. 2004; 16:857-72. [PubMed: 15157665]

15. Cheung J, Smith DF. Molecular chaperone interactions with steroid receptors: an update. Mol Endocrinol. 2000; 14:939-46. [PubMed: 10894145]

16. Ali S, Metzger D, Bornert JM, Chambon P. Modulation of transcriptional activation by liganddependent phosphorylation of the human oestrogen receptor A/B region. EMBO J. 1993; 12:115360. [PubMed: 8458328]

17. Le Goff P, Montano MM, Schodin DJ, Katzenellenbogen BS. Phosphorylation of the human estrogen receptor. Identification of hormone-regulated sites and examination of their influence on transcriptional activity. J Biol Chem. 1994; 269:4458-66. [PubMed: 8308015]

18. Brzozowski AM, Pike ACW, Dauter Z, Hubbard RE, Bonn T, Engstrom O, et al. Molecular basis of agonism and antagonism in the estrogen receptor. Nature. 1997; 389:753-8. [PubMed: 9338790] 
19. Giovannelli P, Di DM, Giraldi T, Migliaccio A, Castoria G, Auricchio F. Targeting rapid action of sex-steroid receptors in breast and prostate cancers. Front Biosci (Elite Ed). 2012; 4:453-61. [PubMed: 22201885]

20. Ordonez-Moran P, Munoz A. Nuclear receptors: genomic and non-genomic effects converge. Cell Cycle. 2009; 8:1675-80. [PubMed: 19448403]

21. Wurtz JM, Bourguet W, Renaud JP, Vivat V, Chambon P, Moras D, et al. A canonical structure for the ligand-binding domain of nuclear receptors. Nat Struct Biol. 1996; 3:87-94. [PubMed: 8548460]

22. Renaud JP, Rochel N, Ruff M, Vivat V, Chambon P, Gronemeyer H, et al. Crystal structure of the RAR-gamma ligand-binding domain bound to all-trans retinoic acid. Nature. 1996; 378:681-9. [PubMed: 7501014]

23. Bourguet W, Ruff M, Chambon P, Gronemeyer H, Moras D. Crystal structure of the ligandbinding domain of the human nuclear receptor RXR-alpha. Nature. 1995; 375:377-82. [PubMed: 7760929]

24. Wagner RL, Apriletti JW, McGrath ME, West BL, Baxter JD, Fletterick RJ. A structural role for hormone in the thyroid hormone receptor. Nature. 1995; 378:690-7. [PubMed: 7501015]

25. Tanenbaum DM, Wang Y, Williams SP, Sigler PB. Crystallographic comparison of the estrogen and progesterone receptor's ligand binding domain. Proc Natl Acad Sci USA. 1998; 95:59986003. [PubMed: 9600906]

26. Shiau AK, Barstad D, Loria PM, Cheng L, Kushner PJ, Agard DA, et al. The structural basis of estrogen receptor/coactivator recognition and the antagonism of this interaction by tamoxifen. Cell. 1998; 95:927-37. [PubMed: 9875847]

27. Egea PF, Mitschler A, Rochel N, Ruff M, Chambon P, Moras D. Crystal structure of the human RXRalpha ligand-binding domain bound to its natural ligand: 9-cis retinoic acid. EMBO J. 2000; 19:2592-601. [PubMed: 10835357]

28. Ignar-Trowbridge DM, Nelson KG, Bidwell MC, Curtis SW, Washburn TF, McLachlan JA, et al. Coupling of dual signaling pathways: epidermal growth factor action involves the estrogen receptor. Proc Natl Acad Sci USA. 1992; 89:4658-62. [PubMed: 1584801]

29. Osada N, Hirata S, Shoda T, Hoshi K. The novel untranslated exon "exon 0T" encoded between the exon 0 and exon 1 of the rat estrogen receptor alpha (ER alpha) gene. Endocr J. 2001; 48:46572. [PubMed: 11603569]

30. Han SJ, Lonard DM, O'Malley BW. Multi-modulation of nuclear receptor coactivators through posttranslational modifications. Trends Endocrinol Metab. 2009; 20:8-15. [PubMed: 19019695]

31. Shupnik MA. Crosstalk between steroid receptors and the c-Src-receptor tyrosine kinase pathways: implications for cell proliferation. Oncogene. 2004; 23:7979-89. [PubMed: 15489915]

32. Kuwahara K, Angkawidjaja C, Matsumura H, Koga Y, Takano K, Kanaya S. Importance of the $\mathrm{Ca} 2+$-binding sites in the $\mathrm{N}$-catalytic domain of a family I.3 lipase for activity and stability. Protein Eng Des Sel. 2008; 21:737-44. [PubMed: 18987131]

33. Wimberly B, Thulin E, Chazin WJ. Characterization of the N-terminal half-saturated state of calbindin D9k: NMR studies of the N56A mutant. Protein Sci. 1995; 4:1045-55. [PubMed: 7549869]

34. Akke M, Forsen S, Chazin WJ. Solution structure of $(\mathrm{Cd} 2+) 1$-calbindin D9k reveals details of the stepwise structural changes along the Apo-> $(\mathrm{Ca} 2+) \mathrm{II} 1->(\mathrm{Ca} 2+) \mathrm{I}$, II2 binding pathway. J Mol Biol. 1995; 252:102-21. [PubMed: 7666423]

35. Evenas J, Forsen S, Malmendal A, Akke M. Backbone dynamics and energetics of a calmodulin domain mutant exchanging between closed and open conformations. J Mol Biol. 1999; 289:60317. [PubMed: 10356332]

36. Choe SY, Kim SJ, Kim HG, Lee JH, Choi Y, Lee H, et al. Evaluation of estrogenicity of major heavy metals. Sci Total Environ. 2003; 312:15-21. [PubMed: 12873394]

37. Fechner P, Damdimopoulou P, Gauglitz G. Biosensors paving the way to understanding the interaction between cadmium and the estrogen receptor alpha. PLoS One. 2011; 6:e23048. [PubMed: 21829690] 
38. Rider CV, Hartig PC, Cardon MC, Wilson VS. Comparison of chemical binding to recombinant fathead minnow and human estrogen receptors alpha in whole cell and cell-free binding assays. Environ Toxicol Chem. 2009; 28:2175-81. [PubMed: 19453209]

39. Martinez-Campa C, Alonso-Gonzalez C, Mediavilla MD, Cos S, Gonzalez A, Ramos S, et al. Melatonin inhibits both ER alpha activation and breast cancer cell proliferation induced by a metal-loestrogen, cadmium. J Pineal Res. 2006; 40:291-6. [PubMed: 16635015]

40. Siewit CL, Gengler B, Vegas E, Puckett R, Louie MC. Cadmium promotes breast cancer cell proliferation by potentiating the interaction between ERalpha and c-Jun. Mol Endocrinol. 2010; 24:981-92. [PubMed: 20219890]

41. Brama M, Gnessi L, Basciani S, Cerulli N, Politi L, Spera G, et al. Cadmium induces mitogenic signaling in breast cancer cell by an ERalpha-dependent mechanism. Mol Cell Endocrinol. 2007; 264:102-8. [PubMed: 17125913]

42. Wilson VS, Bobseine K, Gray LE Jr. Development and characterization of a cell line that stably expresses an estrogenresponsive luciferase reporter for the detection of estrogen receptor agonist and antagonists. Toxicol Sci. 2004; 81:69-77. [PubMed: 15166400]

43. Liu Z, Yu X, Shaikh ZA. Rapid activation of ERK1/2 and AKT in human breast cancer cells by cadmium. Toxicol Appl Pharmacol. 2008; 228:286-94. [PubMed: 18275979]

44. Zang Y, Odwin-Dacosta S, Yager JD. Effects of cadmium on estrogen receptor mediated signaling and estrogen induced DNA synthesis in T47D human breast cancer cells. Toxicol Lett. 2009; 184:134-8. [PubMed: 19041697]

45. Silva E, Lopez-Espinosa MJ, Molina-Molina JM, Fernandez M, Olea N, Kortenkamp A. Lack of activity of cadmium in in vitro estrogenicity assays. Toxicol Appl Pharmacol. 2006; 216:20-8. [PubMed: 16716372]

46. Zhang X, Wang Y, Zhao Y, Chen X. Experimental study on the estrogen-like effect of mercuric chloride. Biometals. 2008; 21:143-50. [PubMed: 17588195]

47. Alonso-Gonzalez C, Gonzalez A, Mazarrasa O, Guezmes A, Sanchez-Mateos S, Martinez-Campa $\mathrm{C}$, et al. Melatonin prevents the estrogenic effects of sub-chronic administration of cadmium on mice mammary glands and uterus. J Pineal Res. 2007; 42:403-10. [PubMed: 17439557]

48. Hofer N, Diel P, Wittsiepe J, Wilhelm M, Degen GH. Dose- and route-dependent hormonal activity of the metalloestrogen cadmium in the rat uterus. Toxicol Lett. 2009; 191:123-31. [PubMed: 19703529]

49. Liu J, Huang H, Zhang W, Li H. Cadmium-induced increase in uterine wet weight and its mechanism. Birth Defects Res B Dev Reprod Toxicol. 2010; 89:43-9. [PubMed: 20151473]

50. Ali I, Penttinen-Damdimopoulou PE, Makela SI, Berglund M, Stenius U, Akesson A, et al. Estrogen-like effects of cadmium in vivo do not appear to be mediated via the classical estrogen receptor transcriptional pathway. Environ Health Perspect. 2010; 118:1389-94. [PubMed: 20525538]

51. Ali I, Damdimopoulou P, Stenius U, Adamsson A, Makela SI, Akesson A, et al. Cadmium-induced effects on cellular signaling pathways in the liver of transgenic estrogen reporter mice. Toxicol Sci. 2012; 127:66-75. [PubMed: 22314386]

52. Hofer N, Diel P, Wittsiepe J, Wilhelm M, Kluxen FM, Degen GH. Investigations on the estrogenic activity of the metallohormone cadmium in the rat intestine. Arch Toxicol. 2010; 84:541-52. [PubMed: 20186393]

53. Zhang W, Yang J, Wang J, Xia P, Xu Y, Jia H, et al. Comparative studies on the increase of uterine weight and related mechanisms of cadmium and p-nonylphenol. Toxicology. 2007; 241:84-91. [PubMed: 17920748]

54. Ramachandran B, Makela S, Cravedi JP, Berglund M, Hakansson H, Damdimopoulou P, et al. Estrogen-like effects of diet-derived cadmium differ from those of orally administered $\mathrm{CdCl}(2)$ in the ERE-luc estrogen reporter mouse model. Toxicol Lett. 2011; 202:75-84. [PubMed: 21195146]

55. Kluxen FM, Hofer N, Kretzschmar G, Degen GH, Diel P. Cadmium modulates expression of aryl hydrocarbon receptorassociated genes in rat uterus by interaction with the estrogen receptor. Arch Toxicol. 2012; 86:591-601. [PubMed: 22127542] 
56. Padilla-Banks E, Jefferson WN, Newbold RR. The immature mouse is a suitable model for detection of estrogenicity in the uterotropic bioassay. Environ Health Perspect. 2001; 109:821-6. [PubMed: 11564618]

57. Crain DA, Janssen SJ, Edwards TM, Heindel J, Ho SM, Hunt P, et al. Female reproductive disorders: the roles of endocrine-disrupting compounds and developmental timing. Fertil Steril. 2008; 90:911-40. [PubMed: 18929049]

58. Schutte, KH. The Biology of Trace Elements, Their Role in Nutrition. J.B. Lippincott Co.; Philadelphia and Montreal: 1964.

59. Krizek M, Senft V, Motan J. Copper and the human body. Cas Lek Cesk. 1997; 136:698-701. [PubMed: 9476382]

60. Chan S, Gerson B, Subramaniam S. The role of copper, molybdenum, selenium, and zinc in nutrition and health. Clin Lab Med. 1998; 18:673-85. [PubMed: 9891606]

61. Christianson DW, Cox JD. Catalysis by metal-activated hydroxide in zinc and manganese metalloenzymes. Annu Rev Biochem. 1999; 68:33-57. [PubMed: 10872443]

62. Cantley LC Jr, Aisen P. The fate of cytoplasmic vanadium. Implications on [NA, K)-ATPase inhibition. J Biol Chem. 1979; 254:1781-4. [PubMed: 217870]

63. Chan PC, Peller OG, Kesner L. Copper(II)-catalyzed lipid peroxidation in liposomes and erythrocyte membranes. Lipids. 1982; 17:331-7. [PubMed: 7098774]

64. Waalkes MP, Fox DA, States JC, Patierno SR, McCabe MJ Jr. Metals and disorders of cell accumulation: modulation of apoptosis and cell proliferation. Toxicol Sci. 2000; 56:255-61. [PubMed: 10910982]

65. Hayes RB. The carcinogenicity of metals in humans. Cancer Causes Control. 1997; 8:371-85. [PubMed: 9498900]

66. IARC Monographs on the evaluation of the carcinogenic risk of chemicals to humans: some metals and metallic compounds. Lyon, France: 1980.

67. Health assessment document for chromium. US Environmental Proctection Agency; Washington, DC: 1984.

68. Chromiun. National Academy of Sciences; Washington, DC: 1974.

69. Cadmium, nickel, some expoxides, miscellaneous industrial chemicals and general considerations on volatile anaesthetics. 11 ed.. International Agency for Research on Cancer, WHO; Lyons, France: 1976.

70. Nickel. National Academy of Sciences; Washington, DC: 1995.

71. Gilman, JPW.; Smierenga, SHH. Inorganic carcinogenesis. In: Searle, CE., editor. Chemical carcinogens, ACS monograph no. 182. 2 ed.. Vol. 1. American Chemical Society; Washington, DC: 1980. p. 577

72. Norseth T. The carcinogenicity of chromium. Environ Health Persp. 1981; 40:121-30.

73. Barlow SM, Sullivan FM. Reproductive hazards and industrial chemicals. Ann Occup Hyg. 1981; 24:359-61. [PubMed: 7325498]

74. Snow ET. Metal carcinogenesis: mechanistic implications. Pharmacol Ther. 1992; 53:31-65. [PubMed: 1641401]

75. Kamamoto Y, Makiura S, Sugihara S, Hiasa Y, Arai M. The inhibitory effect of copper on DLethionine carcinogenesis in rats. Cancer Res. 1973; 33:1129-35. [PubMed: 4122165]

76. Kensler TW, Bush DM, Kozumbo WJ. Inhibition of tumor promotion by a biomimetic superoxide dismutase. Science. 1983; 221:75-7. [PubMed: 6857269]

77. Solanki V, Yotti L, Logani MK, Slaga TJ. The reduction of tumor initiating activity and cell mediated mutagenicity of dimethylbenz[a]anthracene by a copper coordination compound. Carcinogenesis. 1984; 5:129-31. [PubMed: 6418405]

78. Gartell MJ, Craun JC, Podrebarae DS, Gunderson ER. Pesticides, selected elements and other chemicals in adult total diet samples. October 1980-March 1982. J Assoc. Anal Chem. 1986; 69:146-61.

79. Gartell MJ, Craun JC, Podrebarae DS, Gunderson ER. Pesticides, selected elements and other chemicals in infant and toddler total diet samples. October 1980-March 1982. J Assoc. Anal Chem. 1986; 69:123-45. 
80. Moschandreas DJ, Karuchit S, Berry MR, O’Rourke MK, Lo D, Lebowitz MD, et al. Exposure apportionment: ranking food items by their contribution to dietary exposure. J Expo Anal Environ Epidemiol. 2002; 12:233-43. [PubMed: 12087429]

81. Wilhelm M, Wittsiepe J, Schrey P, Budde U, Idel H. Dietary intake of cadmium by children and adults from Germany using duplicate portion sampling. Sci Total Environ. 2002; 285:11-9. [PubMed: 11874034]

82. Muller M, Anke M, Illing-Gunther H, Thiel C. Oral cadmium exposure of adults in Germany. 2: Market basket calculations. Food Addit Contam. 1998; 15:135-41. [PubMed: 9602918]

83. Ysart G, Miller P, Croasdale M, Crews H, Robb P, Baxter M, et al. 1997 UK Total Diet Studydietary exposures to aluminium, arsenic, cadmium, chromium, copper, lead, mercury, nickel, selenium, tin and zinc. Food Addit Contam. 2000; 17:775-86. [PubMed: 11091791]

84. Jarup L, Berglund M, Elinder CG, Nordberg G, Vahter M. Health effects of cadmium exposure-a review of the literature and a risk estimate. Scand J Work Environ Health. 1998; 24(Suppl 1):1-51. [PubMed: 9569444]

85. U.S. Environmental Protection Agency. Health assessment document of cadmium. Office of Research and Development; 1981. EPA-600/8-81, NTIS Pub. PB82-115163

86. Antila E, Mussalo-Rauhamaa H, Kantola M, Atroshi F, Westermarck T. Association of cadmium with human breast cancer. Sci Total Environ (Netherlands). 1996; 186:251-6.

87. Lucis OJ, Lucis R, Shaikh ZA. Cadmium and zinc in pregnancy and lactation. Arch Environ Health. 1972; 25:14-22. [PubMed: 5033275]

88. Sonawane BR, Nordberg M, Nordberg GF, Lucier GW. Placental transfer of cadmium in rats: influence of dose and gestational age. Environ Health Perspect. 1975; 12:97-102. [PubMed: 1227867]

89. Schroeder HA, BALASSA JJ, VINTON WH Jr. Chromium, cadmium, and lead in rats: effects on life span, tumors and tissue levels. J Nutr. 1965; 86:51-66. [PubMed: 14291684]

90. Lucas, JM. Burea of Mines. US Department of the Interior; 1980. Cadmium. Bulletin 671

91. Nriagu, JO. Biogeochemistry of lead in the environment, part 1A. Elsevier; Amsterdam: 1978. Lead in the atmosphere.

92. Jung MC, Thornton I. Environmental contamination and seasonal variation of metals in soils, plants and waters in the paddy fields around a Pb-Zn mine in Korea. Sci Total Environ. 1997; 198:105-21. [PubMed: 9167264]

93. Kazantzis G. Role of cobalt, iron, lead, manganese, mercury, platinum, selenium, and titanium in carcinogenesis. Environ Health Perspect. 1981; 40:143-61. [PubMed: 7023929]

94. Rohr U, Senger M, Selenka F. Effect of silver and copper ions on survival of Legionella pneumophila in tap water. Zentralbl Hyg Umweltmed. 1996; 198:514-21. [PubMed: 9409904]

95. Plockinger B, Dadak C, Meisinger V. Lead, mercury and cadmium in newborn infants and their mothers. Z Geburtshilfe Perinatol. 1993; 197:104-7. [PubMed: 8328167]

96. Claye SS, Idouraine A, Weber CW. In vitro mineral binding capacity of five fiber sources and their insoluble components for copper and zinc. Plant Foods Hum Nutr. 1996; 49:257-69. [PubMed: 8983052]

97. EPA. U.S. Environmental Protection Agency. EPA; Washington, DC: 1980.

98. Peraza MA, Ayala-Fierro F, Barber DS, Casarez E, Rael LT. Effects of micronutrients on metal toxicity. Environ Health Perspect. 1998; 106(Suppl 1):203-16. [PubMed: 9539014]

99. Tamaya T, Nakata Y, Ohno Y, Nioka S, Furuta N. The mechanism of action of the copper intrauterine device. Fertil Steril. 1976; 27:767-72. [PubMed: 181276]

100. Wilhelm M, Lombeck I, Ohnesorge FK. Cadmium, copper, lead and zinc concentrations in hair and toenails of young children and family members: a follow-up study. Sci Total Environ. 1994; 141:275-80. [PubMed: 8178122]

101. Cantor KP, Stewart PA, Brinton LA, Dosemeci M. Occupational exposures and female breast cancer mortality in the United States. J Occup Med. 1994; 37:336-48.

102. Pollan M, Gustavvsson P. High-risk Occupations for breast cancer in Swedish female working population. Am J Public Health. 1999; 89:875-81. [PubMed: 10358678] 
103. McElroy JA, Shafer MM, Trentham-Dietz A, Hampton JM, Newcomb PA. Cadmium exposure and breast cancer risk. J Natl Cancer Inst. 2006; 98:869-73. [PubMed: 16788160]

104. Gallagher CM, Chen JJ, Kovach JS. Environmental cadmium and breast cancer risk. Aging (Albany NY). 2010; 2:804-14. [PubMed: 21071816]

105. Julin B, Wolk A, Bergkvist L, Bottai M, Akesson A. Dietary cadmium exposure and risk of postmenopausal breast cancer: a population-based prospective cohort study. Cancer Res. 2012; 72:1459-66. [PubMed: 22422990]

106. Akesson A, Julin B, Wolk A. Long-term dietary cadmium intake and postmenopausal endometrial cancer incidence: a population-based prospective cohort study. Cancer Res. 2008; 68:6435-41. [PubMed: 18676869]

107. Jia ZG. Analysis of serum levels of selenium, zinc, and copper in 132patients with malignant tumors. Zhonghua Yu Fang Yi Xue Za Zhi. 1991; 25:205-7. [PubMed: 1782822]

108. Capel ID, Pinnock MH, Williams DC, Hanham IW. The serum levels of some trace and bulk elements in cancer patients. Oncology. 1982; 39:38-41. [PubMed: 7058045]

109. Margalioth EJ, Schenker JG, Chevion M. Copper and zinc levels in normal and malignant tissues. Cancer. 1983; 52:868-72. [PubMed: 6871828]

110. Vaidya SM, Kamalakar PL. Copper and ceruloplasmin levels in serum of women with breast cancer. Indian J Med Sci. 1998; 52:184-7. [PubMed: 9808908]

111. Garofalo JA, Ashikari H, Lesser ML, Menendez-Botet C, Cunningham-Rundles S, Schwartz MK, et al. Serum zinc, copper, and the $\mathrm{Cu} / \mathrm{Zn}$ ratio in patients with benign and malignant breast lesions. Cancer. 1980; 46:2682-5. [PubMed: 7448705]

112. Gupta S, Shukla VK, Vaidya MP, Roy SK, Gupta S. Serum trace elements and Cu/Zn ratio in breast cancer. J Surg Oncol. 1991; 46:178-81. [PubMed: 2011029]

113. Yenisey C, Fadiloglu M, Onvural B. Serum copper and ceruloplasmin concentrations in patients with primary breast cancer. Biochem Soc Trans. 1996; 24:321S. [PubMed: 8736979]

114. Garland M, Morris JS, Colditz GA, Stampfer MJ, Spate VL, Baskett CK, et al. Toenail trace element levels and breast cancer: a prospective study. Am J Epidemiol. 1996; 144:653-60. [PubMed: 8823061] 


\section{Structure and Function of Estrogen Receptor- $\alpha$}

\begin{tabular}{|c|c|c|c|c|}
\hline $\mathrm{A} / \mathrm{B}$ & $\mathrm{C}$ & D & $\mathrm{E}$ & $\mathrm{F}$ \\
\hline $\begin{array}{c}\text { AF-1 } \\
\text { (Transactivation Function-1) }\end{array}$ & $\begin{array}{c}\text { DBD } \\
\text { (DNA Binding } \\
\text { Domain) }\end{array}$ & & $\begin{array}{c}\text { AF-2 } \\
\text { (Transactivation } \\
\text { Function-2) }\end{array}$ & \\
\hline & & & $\begin{array}{c}\text { LBD } \\
\begin{array}{c}\text { (Ligand Binding } \\
\text { Domain) }\end{array}\end{array}$ & \\
\hline & & & $\begin{array}{l}{ }^{*} \text { metal } \\
\text { binding site }\end{array}$ & \\
\hline
\end{tabular}

Fig. 1.

Structure and function of estrogen receptor-alpha. Based on similarities to other nuclear receptors, ERa is divided into regions A through $\mathrm{F}$. The $\mathrm{N}$-terminal $\mathrm{A} / \mathrm{B}$ region contains the transactivation function-1 (AF-1) domain that plays an important role in ligand dependent and independent activation of the receptor. Region $\mathrm{C}$ is the DNA binding domain (DBD) that is responsible for binding to target genes. Region $\mathrm{D}$ is the hinge region and plays a role in dimerization of the receptor. Region $\mathrm{E}$ is the ligand binding domain (LBD) that binds hormone and metals. Region E contains the transactivation function-2 (AF-2) domain that is responsible for ligand dependent activation, dimerization, and recruitment of cofactors to the receptor 


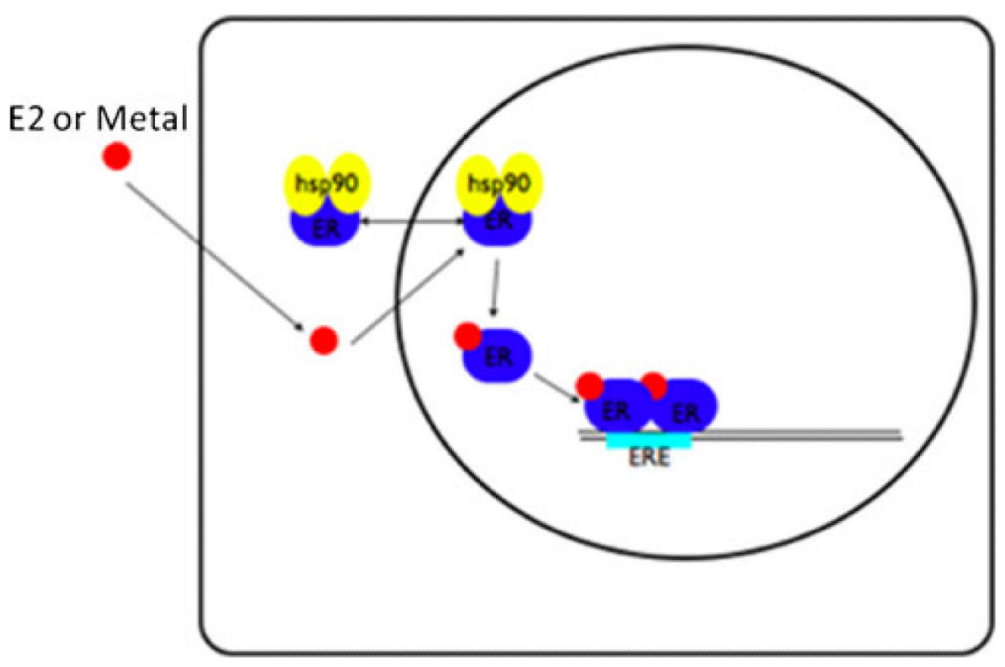

Fig. 2.

Classical genomic pathway of estrogen receptor-alpha: proposed role of metals. In the absence of ligand, ERa is associated with a complex containing heat shock proteins and immunophilins that maintains the LBD in a high affinity, ligand binding conformation and prevents the receptor from dimerizing and binding to DNA and cofactors. Following the binding of metals, it is proposed that, similar to estradiol, the receptor is phosphorylated on serines in the A/B region that increases the activity of the AF-1 domain and a conformational change occurs in the LBD that results in the dissociation of the heat shock complex and the formation of the AF-2 domain, the coactivator binding site. The activated receptor then localizes in the nucleus, dimerizes, binds to an ERE, and recruits coactivators and RNA polymerase II to the promoters of target genes 


\section{Conformational Changes in the Ligand Binding Domain - Model}

(a) Apo-LBD

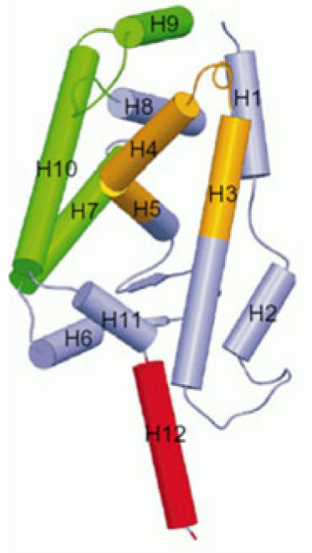

(b) Holo-LBD

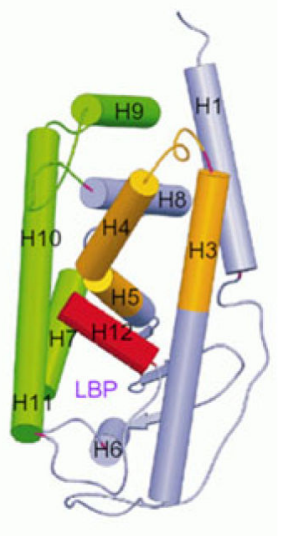

(c) Apo Conformation

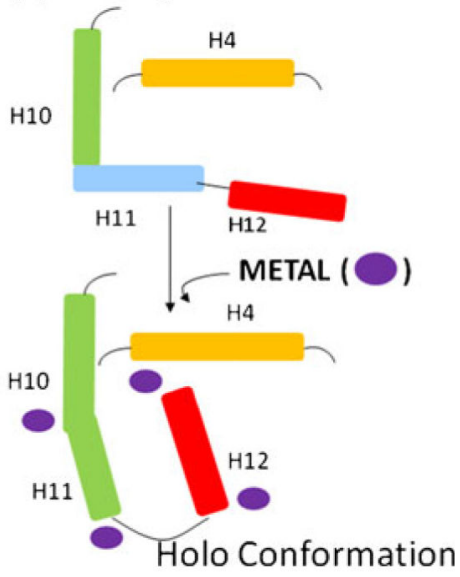

Fig. 3.

Model of conformational changes in the ligand binding domain induced by metals.

Schematic drawing of the unliganded (apo) ligand binding domain of retinoid X receptor (a) and the agonist bound (holo) ligand binding domain of retinoid receptor (b). Comparison of helices H4, H10, H11, and H12 in the liganded (apo) and unliganded (holo) conformation (c). In the absence of ligand, helices H10 and H11 are separated by a short loop with helix $\mathrm{H} 11$ positioned at an angle to helix $\mathrm{H} 10$ and helix $\mathrm{H} 12$ is positioned to the side of the ligand binding pocket (LBP). In the presence of ligand, helix $\mathrm{H} 12$ is repositioned over the ligand binding pocket and helix $\mathrm{H} 11$ is repositioned adjacent to helix $\mathrm{H} 10$ forming a continuous helix. In the proposed model, interaction of the metal (shown as purple circles) with ERa induces conformational changes that mimic the conformational changes induced by the ligand estradiol. Adapted with permission from Bourguet et al. Trends Pharmacol Sci 2000;21:381-8 